\title{
Consumer debt relief in South-Africa - Should the insolvency system provide for NINA debtors? Lessons from New Zealand
}

Hermie Coetzee

BCom Law LLB LLM (by dissertation) (University of Pretoria). Senior Lecturer, Department of Mercantile Law, Faculty of Law, University of Pretoria.

Melanie Roestoff

BLC LLB LLM LLD (University of Pretoria). Professor, Department of Mercantile Law, Faculty of Law, University of Pretoria.

Email: $\quad$ hermie.coetzee@up.ac.za / melanie.roestoff@up.ac.za

Tel: $\quad+27124202363$

Fax: $\quad+27124204010$

Physical address: $\quad$ Room 3.8, New Law Building

University of Pretoria

Cnr Lynnwood and Roper

Hatfield

0002

\begin{abstract}
South African natural person insolvency law has remained largely creditor-orientated despite the international trend to assist over-indebted debtors. Furthermore, although the South African system provides for a number of debt relief procedures, the entry requirements are of such a nature that most debtors are effectively excluded from any form of relief and therefore bound to their desperate situations. The majority of these excluded debtors fall within the no income and no assets (the so-called No Income No
\end{abstract}


Asset (NINA) debtors) category-the main feature of this article. In the South African insolvency system, a person can therefore be 'too poor to go bankrupt'. With reference to international principles and a thorough comparative study of the New Zealand system, the South African system is analysed, and some recommendations are made in order to provide a more accessible, effective and nondiscriminate system with specific focus on the plight of the NINA debtor. This is done by keeping the complex South African debt and poverty situation in mind as it is acknowledged that any reform should take cognisance of the unique socio-economic and cultural background. It is recognised that providing relief to the NINA category debtors will have an impact on the economy. However, it is submitted that the exclusion of this group will be even more expensive as it creates an obstacle for these debtors to enter the formal sector and economy, thereby discouraging broader economic growth.

\section{Introduction}

Despite the world-wide trend to accommodate over-burdened consumer debtors seeking debt relief, the South African insolvency system has remained largely creditororientated and does not provide adequate relief to over-indebted consumers. ${ }^{1}$ Furthermore, though the South African system provides for a number of debt relief procedures, the entry requirements are of such a nature that most debtors are effectively excluded and therefore bound to their desperate plight. $^{2}$

\footnotetext{
* BCom Law LLB LLM (by dissertation) (University of Pretoria). Senior Lecturer, Department of Mercantile Law, Faculty of Law, University of Pretoria.

** BLC LLB LLM LLD (University of Pretoria). Professor, Department of Mercantile Law, Faculty of Law, University of Pretoria.

${ }^{1}$ See M Roestoff and H Coetzee, 'Consumer Debt Relief in South Africa; Lessons from America and England; and Suggestions for the Way Forward', (2012) 24 SA Merc LJ 53.

${ }^{2}$ See Roestoff and Coetzee (n 1) 59.
} 
Over-indebted South African consumers presently have three statutory debt relief measures at their disposal. ${ }^{3}$ These procedures are to be found in various pieces of legislation and only one, sequestration in terms of the Insolvency Act, ${ }^{4}$ provides for a discharge of pre-insolvency debt..$^{5}$ The other two measures are the administration procedure in terms of section 74 of the Magistrates' Courts Act $^{6}$ and debt review in terms of section 86 of the National Credit Act. ${ }^{7}$ It is important to note that a discharge is not the main aim of the sequestration procedure and is merely a consequence thereof. ${ }^{8}$ More distressing, however, is that the majority of over-indebted consumers do not have access to any statutory debt relief measure and that this marginalised group typically consists of people who have no income and no assets (the so-called No Income No Asset (NINA) debtors). ${ }^{9}$ The last possible resort for these debtors is to enter into voluntary negotiations with creditors to agree on a debt-rearrangement. However, due to the low level of disposable income of these debtors, a re-arrangement would probably be an unrealistic prospect. Many creditors will probably not co-operate at all and where there are multiple creditors, such attempts are at best a trying endeavour. Also, there is no statutory

\footnotetext{
${ }^{3}$ See in general Lienne Steyn, 'Statutory regulation of forced sale of the home in South Africa' (LLD thesis, University of Pretoria 2012) 349 et seq for a thorough explanation and consideration of the statutory measures.

${ }^{4} 24$ of 1936.

${ }^{5} \mathrm{~S} 129$.

${ }^{6} 32$ of 1944 .

${ }^{7} 34$ of 2005 .

8 See Ex parte Ford and Two Similar Cases [2009] 3 SA (WCC) 376; Ex parte Shmukler-Tshiko and another and 13 other cases [2013] JOL 29999 (GSJ).

9 Included in this concept are also the low income and low assets (the so-called Low Income Low Asset (LILA)) debtors. In 1998, in England, the Department of Constitutional Affairs announced a review of enforcement of civil court judgments, which amongst others re-evaluated the English administration order scheme. Independent research commissioned by the Department identified three types of debtors, namely, the so-called 'could pays', 'can't pays' (i.e. the NINA and LILA debtors) and 'won't pays'- see 'A Choice of Paths: Better Options to Manage Over-Indebtedness and Multiple Debt' (2004) 37. See also Donna McKenzie Skene and Adrian Walters, 'Consumer Bankruptcy Law Reform in Great Britain' (2006) 80 Am. Bankr. L.J. 477; Melanie Roestoff and Stéfan Renke, 'Debt Relief for Consumers - The Interaction between Insolvency and Consumer Protection Legislation (Part 2)' (2006) 27 Obiter 98, 108.
} 
'back-up' for such negotiations and arrangements resulting from them. In the South African insolvency system, a person can therefore be 'too poor to go bankrupt' ${ }^{10}$

According to the World Bank the preferred position when dealing with NINA debtors is to avoid discrimination based on financial means by providing the same relief to all debtors. ${ }^{11}$ Some developed countries ${ }^{12}$ such as New Zealand have indeed specifically and directly addressed the needs of this particular group of debtors. New Zealand has recently reformed its insolvency law by inter alia introducing a new Insolvency Act. ${ }^{13}$ This Act provides for bankruptcy ${ }^{14}$ and alternative measures, ${ }^{15}$ in the form of proposals, ${ }^{16}$ summary instalment orders, ${ }^{17}$ and the no asset procedure. ${ }^{18}$

This article commences with a brief description of the present consumer debt and poverty situation in South Africa as background. Thereafter, the statutory debt relief mechanisms available to insolvent or over-indebted consumers are set out with specific emphasis on the requirements for access to these measures and the relief offered. This will

10 Michael R, Rochelle, 'Lowering the Penalties for Failure: Using the Insolvency Law as a Tool for Spurring Economic Growth; the American Experience, and Possible Uses for South Africa', (1996) 2 TSAR 315, 319.

11 The World Bank, Report on the Treatment of the Insolvency of Natural Persons (2012) 99, http://wwwwds.worldbank.org/external/default/WDSContentServer/WDSP/IB/2013/05/02/000333037 20130502131241/Rendered/PDF/771700WP0WB0In00Box377289B00PUBLIC0.pdf 'accessed 30

May 2013'.

12 See the debt relief order in England and Wales - Debt relief orders were created by s 108(1) of the Tribunals Courts and Enforcement Act 2007 (c.15) and were detailed in Scheds 17 to 20 of the Act. The new provisions are contained in part 7A of the Insolvency Act 1986 and consist of ss 251A to 251X read with the relevant schedules thereto. See also Roestoff and Coetzee (n 1) 59.

13 Public Act 2006 No 55. The Act was assented to on 7 November 2006 and was brought into force on 3 December 2007 by the Insolvency Act Commencement Order 2007 (SR 2007/332). The Act specifically excludes corporations, associations or a company incorporated or registered under any Act from bankruptcy adjudication or any of the alternative measures. Corporate insolvency is regulated by the Companies Act 1993 (NZ).

14 See Part 2 in general.

15 S 8

16 Pt 5 sub-pt 2, ss 325-339.

17 Pt 5 sub-pt 3, ss 340-360.

18 Pt 5 sub-pt 4, ss 361-377B. 
illustrate the lack of and need for a measure catering for NINA debtors, which is the core feature of this article. We also consider reform initiatives currently on the table to determine whether there is a possibility that the system will improve as far as this particular group is concerned. The insolvency procedures in New Zealand with specific focus on the no asset procedure are discussed next. The purpose is to compare the two systems in order to identify the lessons to be learnt from the New Zealand system. This is followed by our recommendations for South Africa and conclusions.

\section{Socio-economic conditions and levels of over-indebtedness in South Africa}

It is important to understand the reality and background against which this research is intended. In the discussion below an indication of the levels of over-indebtedness and some of the socio-economic conditions that South Africans face today are therefore given.

The South African economy is regularly described as dual in nature as it contains two different sectors, namely, the developed economy and the underdeveloped or developing economy, with almost no middle ground. ${ }^{19}$ This dualism provides for a complex socio-economic environment. Even though South Africa can compare to developed economies in certain respects, the other side of the coin looks very different. The latest World Banks statistics estimate the South African poverty rate (as a percentage of the population living below the national poverty line) at $31 \%$ in $1995,38 \%$ in 2000 and

19 For a general discussion of the socio-economic context and social policy needs in South Africa see MP Olivier, N Smit and ER Kalula, Social Security: A Legal Analysis (LexisNexis Butterworths 2003). 
$23 \%$ in $2006 .{ }^{20}$ Furthermore, Statistics South Africa reflects the percentage unemployed persons $^{21}$ at $25.2 \%$ for the first quarter of $2013,{ }^{22}$ which ranks amongst the highest in the world. ${ }^{23}$ According to Finance Minister, Pravin Gordhan, of the estimated 52.98 million South Africans, ${ }^{24}$ nearly 16 million (almost a third) receive social grants. ${ }^{25}$ The number of South Africans liable for personal income tax stands in stark contrast to this figure. Even though the South African Revenue Services (SARS) reported a growth in the individual tax register from 1.7 million in 1994 to 6 million in 2010, the number is still very low. Furthermore, SARS reported a further growth to 13.7 million in 2012 following a policy change to register all individuals in formal employment. ${ }^{26}$ This figure obviously does not reflect the number of individuals actually liable for or paying personal income tax, as all salary earners, irrespective of whether they are liable for individual income tax, must now be registered with SARS.

20 The World Bank, Poverty Headcount Ratio at national poverty line (\% of population) $<$ http://data.worldbank.org/country/south-africa> 'accessed 31 May 2013'.

21 The report defines unemployed persons as those (aged 16-64) years) who:

a) were not employed in the reference week and;

b) actively looked for work or tried to start a business in the four weeks preceding the survey interview and;

c) were available for work, i.e. would have been able to start work or a business in the reference week or;

d) had not actively looked for work in the past four weeks but had a job or business to start at a definite date in the future and were available.

22 Statistics South Africa, Quarterly Labour Force Survey (Statistical Release P0211, 6 May 2013) $<$ http://www.statssa.gov.za/publications/P0211/P02111stQuarter2013.pdf $>$ 'accessed 31 May 2013'.

23 See also The World Bank, South Africa Economic Update: Focus on Savings, Investment and, Inclusive Growth (July 2011) < http://siteresources.worldbank.org/INTSOUTHAFRICA/Resources/SAEUJuly 2011 Full Report.pdf > 'accessed 31 May 2013'.

24 Statistics South Africa, 2013 Mid year Population Estimates (Statistical release P0302, 14 May 2013) $<$ http://www.statssa.gov.za/publications/P0302/P03022013.pdf $\geq$ 'accessed 31 May 2013'.

25 Pravin Gordhan, $2012 \quad$ Budget Speech (22 February 2012$)$ $<$ http://www.treasury.gov.za/documents/national\%20budget/2012/speech/speech.pdf $>$ 'accessed 31 May 2013'. When this statement was made the statistics available recorded an estimated 50.59 million South Africans. The 2012 release was delayed.

26 Oupa Magashula, Address by the Commissioner of SARS to the Standing Committee on finance on the 2011 Tax Statistics (23 May 2012) <http://www.sars.gov.za/home.asp?pid=64671> 'accessed 2 October 2012'. See also National Treasury and the South African Revenue Services, 2012 Tax Statistics (25 October 2012) < http://www.sars.gov.za/AllDocs/SuppDocs/Reports/SARS-Stats-2012-02\%20\%20Tax \%20Statistic\%20Full\%20Document\%20for\%20the\%20year\%202012.pdf> 'accessed 31 May 2013'. 
Since June 2007 there has been an on-going decline in the number of South African consumers in 'good standing'. ${ }^{27}$ At the end of December 2012, credit bureaux had records of 19.97 million credit active consumers, of which 9.34 million had impaired credit records. Thus, at present only $53.2 \%$ of credit-active consumers are in 'good standing, ${ }^{28}$ which is a clear indication of the urgent need to afford some form of relief to over-burdened consumers. The National Credit Act, which became fully effective on 1 June 2007, shielded South Africa to some extent from the worst of the worldwide economic meltdown. The stringent measures to prevent reckless credit granting and overindebtedness appears to have come at just the right time, but unfortunately, as is indicated below, the Act offers no remedial measures once a consumer finds him- or herself in a debt trap.

If a debtor in South Africa fails to pay his or her debt, the creditor will eventually obtain judgment (in most instances default judgment) against such debtor. ${ }^{29}$ It is important to note that no natural person with full contractual capacity is protected from debt enforcement procedures prior to a court order placing such person under one of the debt relief measures as mentioned above. Once a credit provider has obtained a judgment it will only prescribe after a period of 30 years has lapsed. ${ }^{30}$ In practice, even though it may be difficult to collect on such debt, these debtors are harassed by credit providers

27 'Good standing' refers to 'An account or consumer showing as current or on which the client has not missed more than one or two instalments, which has no adverse listings and has no judgments.' National Credit Regulator, Credit Bureaux Monitor First Quarter (December 2012) - available at www.ncr.org.za 'accessed 31 May 2013'.

28 National Credit Regulator (n 27).

29 In most cases judgment will be obtained from the magistrates' courts. These are the lower courts which function within the framework of the Magistrates' Courts Act 32 of 1944.

30 This statement is concerned with extinctive prescription - Prescription Act 68 of 1969, s 11. The Act applies to debts arising after 1 December 1970. There are two forms of prescription, namely extinctive and acquisitive prescription. Extinctive prescription refers to the situation where legal obligations are extinguished through lapse of time whilst acquisitive prescription refers to the situation where ownership of another's property can be acquired once a period of 30 years have lapsed. 
and can technically be the subject of harassment for a period of at least 30 years. ${ }^{31}$ In the event that a debtor is employed in the formal sector, a common collection instrument, the emoluments attachment order, may be used to effectively collect on the judgment debt. ${ }^{32}$ In terms of such an order an employer is obliged to deduct instalments from the debtor's salary and pay these amounts over to the creditor. ${ }^{33}$ There is no statutory prescription as to the percentage of the salary or wage that may be attached. Furthermore, neither the credit provider nor the clerk of the court granting the order is aware of other emoluments attachment orders already made against the debtor's salary. There is generally no enquiry into the financial affairs of the debtor and the creditor often unilaterally decides on the amount of the instalment. If a substantial part (or the whole of - which is not a rare phenomenon) of a debtor's salary is attached in this manner, it leaves the latter with no means to provide for him- or herself and dependants. ${ }^{34}$ The debtor is in such instances forced to resign ${ }^{35}$ and seek employment in the informal sector. ${ }^{36}$ The system forces these debtors to such measures as they are not protected by the law. If they cannot find a source of income in the informal sector, these debtors become a social burden on the South African economy. It is therefore submitted that some aspects of the individual enforcement system coupled with the exclusivity of the broader insolvency regime entrenches the reality of the dual South African economy. The system in some instances retains these 'poor' South Africans in a state of poverty or even worse, forces

31 See in general University of Pretoria Law Clinic, The incidence of and the undesirable practices relating to garnishee orders in South Africa (GTZ 2008).

32 Magistrates' Courts Act 32 of 1944, s 65J. See in general University of Pretoria Law Clinic (n 31).

33 Magistrates' Courts Act 32 of 1944, s 65J.

34 See University of Pretoria Law Clinic (n 31) 74.

35 See Juliet Pitman, 'A multi-pronged attach: SAB Ltd takes a comprehensive approach' in Elsa Crous (ed), Employee financial wellness: A corporate social responsibility (GTZ 2008) 152.

36 The informal sector refers to the unstructured economy in developing countries where individuals are not formally employed, but are engaged in entrepreneurial activities which does not adhere to legal requirements, standards and procedures. Such individuals refrain from entering the formal economy as once they do so, their wages will again be attached. These entrepreneurs are amongst others street vendors, hairdressers, musicians, artisans etc. 
consumers to exit the formal employment sector which may result in them becoming NINA debtors.

\section{South African debt relief measures}

\subsection{Introduction}

The three statutory debt relief measures available to some over-extended South African consumers will be discussed and analysed in this section. It is important to take note of the multiplicity of regulators, intermediaries, access requirements, procedures, decision making forums and legislation in order to fully comprehend the intricacies of the South African insolvency landscape and the exclusion of the NINA debtor. Sequestration in terms of the Insolvency Act will firstly be discussed as it is deemed to be the primary debt relief measure, because it is the only statutory measure that provides a discharge of pre-insolvency debt. The administration procedure in terms of section 74 of the Magistrates' Courts Act and debt review in terms of section 86 of the National Credit Act will consequently be discussed. Reform initiatives will lastly be considered to ascertain whether it will fill some of the gaps in the current system. Each of these measures will in conclusion be analysed as to their appropriateness to the NINA situation.

\subsection{Sequestration}

The primary object of the South African Insolvency Act is to ensure an orderly and fair distribution of the debtor's assets in circumstances where these assets are insufficient to satisfy all the creditors' claims. Once a sequestration order has been made a concursus creditorum comes into being and the rights of the creditors as a group are preferred to the rights of individual creditors. ${ }^{37}$ As mentioned, it is not a primary object of the Insol-

37 Walker v Syfret [1911] AD 141, 166; Eberhard Bertelsmann and others, Mars the Law of Insolvency in South Africa (Chris Nagel ed, $9^{\text {th }}$ edn, Juta 2008) 2. 
vency Act to grant debt relief to debtors. ${ }^{38}$ However, one of the Act's consequences is that debt relief is granted to the consumer debtor as rehabilitation in terms of the Act results in a discharge of all pre-sequestration debts. ${ }^{39}$

In terms of the South African Insolvency Act, a debtor's estate may be sequestrated by way of voluntary surrender ${ }^{40}$ or subsequent to a successful application by a creditor or two or more creditors for the compulsory sequestration of his or her estate. ${ }^{41}$ These procedures are expensive and require a high court application. ${ }^{42}$ Moreover, the South African Insolvency Act lays down 'advantage for creditors' ${ }^{43}$ as a pre-requisite for sequestration applications. This requirement is fundamental to the South African Insolvency Act and has been part of South African insolvency legislation since $1916 .{ }^{44}$ As Erasmus J remarked: '[T] he whole tenor of the Act, inasmuch as it directly relates to sequestration proceedings, is aimed at obtaining a pecuniary benefit for creditors. ${ }^{45}$ The advantage to creditors requirement is not defined in the Insolvency Act. According to case law it entails a 'reasonable prospect of some pecuniary benefit ${ }^{46}$ to the general body of creditors' ${ }^{47}$ South African case law also suggests that the courts have a duty to scruti-

38 See Ex parte Ford and Ex parte Shmukler-Tshiko (n 8).

39 Insolvency Act 24 of 1936, s 129(b). See Bertelsmann (n 37) 3.

40 Ss $3-7$.

41 Ss 9-12.

42 See Roestoff and Renke (n 9) 99.

43 See ss 6, 10 and 12.

44 See ss 10 and 12 of the Insolvency Act 32 of 1916.

45 BP Southern Africa (Pty) Ltd v Furstenburg [1966] 1 SA (O) 717, 720.

46 The Act does not prescribe the size of the dividend, and in the past the South African courts have set, as a rule of practice, the minimum dividend on 10 cents in the Rand for each concurrent creditor (Nieuwenhuizen and Another $v$ Nedcor Bank Ltd [2001] 2 All SA 364 (O) 367; Ex parte Kelly [2008] 4 SA 615 (T) 617). In recent times, however, a dividend of 20 cents in the Rand is generally regarded as the minimum benefit that would have to be established before a sequestration application will be granted (Ex parte Ogunlaja \& Others [2011] JOL 27029 (GNP) a 9).

47 See Meskin \& Co v Friedman [1948] 2 SA (W) 555, 559; Lynn \& Main Inc v Naidoo [2006] 1 SA (N) 59, 68; Ex parte Bouwer \& Similar Applications [2009] 6 SA (GNP) 382, 386. 
nise sequestration applications to ensure advantage to creditors and to prevent prejudice to them. ${ }^{48}$

According to case law, the essence of 'advantage to creditors' is that the court must make a decision on the evidence presented that there are sufficient assets in the estate with sufficient value to pay the costs of sequestration and a not-negligible dividend to creditors. ${ }^{49}$ In this regard, our courts have recently insisted more stringently on exact information regarding the debtor's affairs being placed before them and on demanding a realistic calculation of the potential dividend. ${ }^{50}$ The reason for this stringent approach is explained as follows by Bertelsmann: ${ }^{51}$

The requirement that all information presented to the court in an application for surrender must be accurate and that the valuations must be exact arises from the courts' insistence that a debtor who is pressed by his creditors does not overestimate the value of his estate in order to obtain relief from his financial burdens. The administration of insolvent estates has over the years developed into a very lucrative and therefore competitive profession. The pressure has therefore

48 See eg Craggs v Dedekind; Baartman v Baartman and Another; Van Aardt v Borrett [1996] 1 SA (C) 935, 937; Ex parte Steenkamp and Related Cases [1996] 3 SA (C) 822, 825; Van Eck v Kirkwood [1997] 1 SA (SE) 289, 290; Van Rooyen v Van Rooyen (Automutual Investements (EC) (Pty) Ltd, Intervening Creditor) [2000] 2 All SA (SE) 485, 490; Beinash \& Co v Nathan [1998] 3 SA (W) 540, 542; Lemley $v$ Lemley [2009] JDR 0445 (SE) 4. Because sequestration can eventually afford a debtor a discharge of his or her debts, the process of compulsory sequestration has in the past been used - or according to some, abused - by debtors in the form of an application for a so-called friendly sequestration to obtain debt relief. See Roger G Evans, 'Friendly Sequestrations, the Abuse of the Process of Court, and Possible Solutions for Overburdened Debtors', (2001) 13 SA Merc LJ 485. See also Esterhuizen v Swanepoel and Sixteen Other Cases [2004] 4 SA (W) 89, 92. This phenomenon has developed in practice because of the fact that the onus of proving advantage in the case of a compulsory sequestration application is less onerous than in the case of a voluntary sequestration application. Unlike voluntary surrender which requires positive proof of advantage for creditors, compulsory sequestration requires only a 'reasonable prospect' that it will be to the advantage of creditors - compare the wording of the Insolvency Act 24 of 1936, ss 10(c) and 12(1)(c). Furthermore no formal requirements are prescribed with regard to compulsory sequestration - Catherine Smith, 'Friendly and Not so Friendly Sequestrations', (1981) 3 Modern Business Law 58, 59. However, also regarding applications for voluntary surrender, the South African courts have of late tightened their approach in order to thwart abuse of process. Ex parte Bouwer (n 47). See Bertelsmann (n 37) 63.

${ }^{49}$ Ex parte Mattysen et Uxor (First Rand Bank Ltd Intervening) [2003] 2 SA (T) 308, 316

${ }^{50}$ Ex parte Bouwer (n 47).

${ }^{51}$ Bertelsmann (n 37) 63, quoted with approval in Ex parte Bouwer (n 47) 384. 
increased to identify debtors whose sequestration or liquidation may render a lucrative return to lawyers, trustees, liquidators, valuators and auctioneers. Advertisements in the media canvassing debtors who are desirous of ridding them of their financial burdens have become commonplace. This has increased the risks for debtors and creditors alike. Debtors who might be able to meet their obligations if they were given the opportunity to properly arrange their affairs, are pressurized into opting for insolvency proceedings instead, often if not always losing their homes and motor vehicles as a result thereof, suffering the consequences of a bad credit record for many years thereafter. On the other hand, insolvency practitioners are tempted to present a rosy picture of the debtor's affairs that bears little semblance to reality, resulting in an estate being declared insolvent that renders little or no dividend for creditors once the fees of the various participants in voluntary surrender proceedings have been deducted and the administration costs have been paid.'

Advantage therefore clearly restricts a debtor's access to this form of debt relief - and a debtor may thus be 'too poor to go bankrupt'.52 It should also be mentioned that the Law Reform Commission has recommended that the advantage for creditors requirement be retained. ${ }^{53}$ From the 2010 Insolvency Bill it would appear that the Commission has not changed its mind in this regard. ${ }^{54}$ The Commission has not expressly indicated its reasons for recommending that the advantage requirement be retained, but it would

52 Rochelle (n 10) 319.

53 South African Law Commission, Report on the Review of the Law of Insolvency (Project 63) Vol 1 (Explanatory Memorandum) and Vol 2 (Draft Bill) (February 2000) - hence the '2000 Explanatory Memorandum' and '2000 Insolvency Bill' respectively. See 2000 Insolvency Bill, cls 7(1)(b) and 8(1)(c) and the 2000 Explanatory Memorandum, 15.

54 See cls 3(8)(a)(ii), 10(1)(c)(i) and 11(1)(c) of the latest version of the Insolvency Bill dated 30 June 2010, the unofficial working copy, on file with the authors (hence the '2010 Insolvency Bill'). See further para 3.5 below regarding the insolvency law reform initiatives. 
appear that the Commission's motivation in this regard is to ensure that sequestration, which is an expensive process to follow, would only be resorted to if it would be costeffective to do so: that is, if the proceeds of the free residue would be sufficient to cover the costs of sequestration and to provide a not-negligible dividend to creditors. ${ }^{55}$

Concerning the administration of a sequestrated estate, the Master of the High Court ${ }^{56}$ is tasked with the supervision of South African insolvency law in the narrow sense. ${ }^{57}$ Although difficult to define its role, it can be said that it is that of a regulator. After appointment, control of the estate vests in the trustee who inter alia has the power and duty to realise property and distribute the proceeds among creditors as provided for in the Act. $^{58}$

\subsection{Administration}

Administration orders are regulated by section 74 of the Magistrates' Courts Act. ${ }^{59}$ Boraine $^{60}$ describes the order as 'a debt relief measure available to some debtors that find themselves in financial distress, which affords them the opportunity to obtain a statutory rescheduling of debt sanctioned by a court order'.

55 See also Barend Hendrik Swart, 'Die Rol van ' $n$ Concursus Creditorum in die Suid-Afrikaanse Insolvensiereg' (LLD, University of Pretoria 1990); Melanie Roestoff, " $n$ Kritiese Evaluasie van Skuldverligtingsmaatreëls vir Individue in die Suid-Afrikaanse Insolvensiereg' (LLD, University of Pretoria 2002); Evans (n 48) 488.

56 The Master of the High Court is a 'creature of statute' as it only possesses the powers and has the duties conferred on it by law. See in general Juanita Christelle Calitz, 'A Reformatory Approach to State Regulation of Insolvency Law in South Africa' (LLD thesis, University of Pretoria 2009).

57 The Master of the High Court does not oversee the debt review and administration procedures.

58 See Bertelsmann (n 37), ch 15 on the rights and duties of the trustee.

5932 of 1944.

${ }^{60}$ André Boraine, 'Some Thoughts on the Reform of Administration Orders and Related Issues', (2003) 36 De Jure 217. 
Administration involves a relatively simple and inexpensive procedure whereby overcommitted debtors' obligations are rescheduled. ${ }^{61}$ These orders are intended for smaller estates where sequestration would 'swallow the assets" ${ }^{62}$ and the aim is mainly to assist the debtor during a period of financial embarrassment. ${ }^{63}$ The procedure does not provide for any discharge of debts or costs ${ }^{64}$ and no maximum time limit in relation to the payment is set. The order will only lapse once all listed creditors as well as the cost of administration have been paid in full. ${ }^{65}$

Administration orders are intended to be utilised where the debtor is unable to satisfy a judgment debt or to meet his or her financial obligations and where he or she does not have sufficient assets to attach in satisfaction of such judgment or obligations. ${ }^{66}$ However, in some instances the court may authorise the administrator, appointed by the court and tasked with the administration of these estates, to sell some of the assets in order to distribute the proceeds amongst creditors. ${ }^{67}$ The administration order can thus be seen as a hybrid debt relief measure as it makes provision for both the rescheduling of debt and the realisation of assets to service debts. Once the order has been granted, creditors may in principle not continue with individual enforcement procedures, ${ }^{68}$ but administration is no bar to sequestration of the debtor's estate. ${ }^{69}$

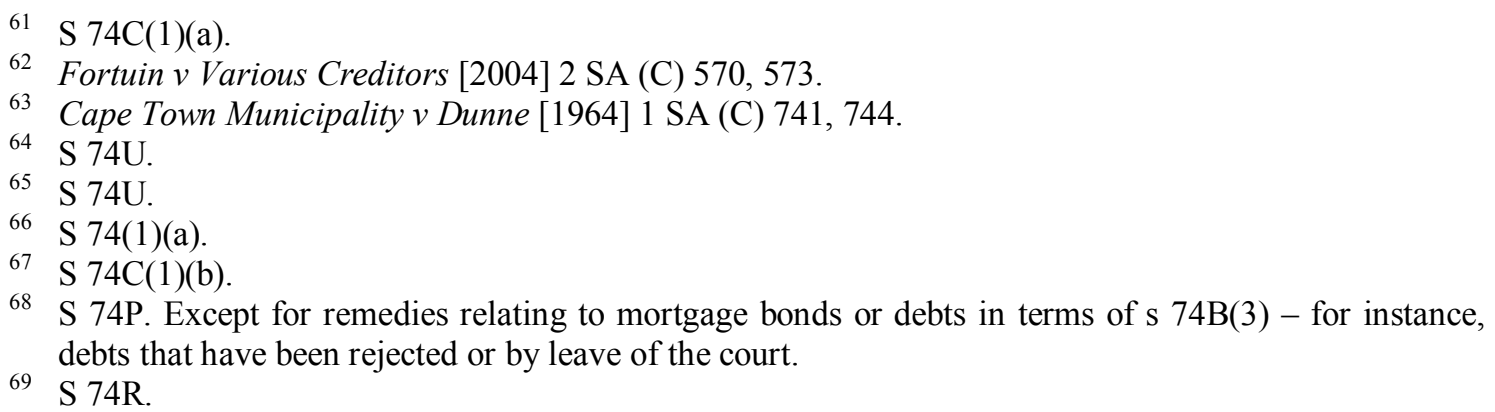


A condition for employing this procedure is that the total amount of all debts due should not exceed the amount determined by the Minister by notice in the Gazette. ${ }^{70}$ The amount is currently set at R50 000 (NZ\$6 283.05 or US\$5 110.90). ${ }^{71}$ Furthermore 'debts' are debts 'due and payable' and do not include in futuro debts. ${ }^{72}$

Not all debtors in financial distress are able to apply for administration. A debtor who cannot show an advantage to creditors will also be excluded from employing the administration procedure where the debt amounts to more than the stated threshold - which clearly did not keep track of reality as it was last revised in 1998. The administration procedure is stigmatised and criticised, one of the major reasons for the negativity being that there is no registration of or body regulating administrators per se. ${ }^{73}$ The Magistrates' Courts Act, however, lists some duties for administrators and empowers the court to deal with non-compliance. ${ }^{74}$

In July 2000, the Department of Justice and the Law Society of South Africa requested the Centre for Advanced Corporate and Insolvency Law at the University of Pretoria to investigate the reform of the administration procedure. The research results were incorporated in a report submitted to the Department of Justice as the Interim Report on the Review of Administration Orders in terms of Section 74 of the Magistrates' Courts Act 32 of 1944. The matter was referred to the South African Law Reform Commission for

$70 \mathrm{~S} 74(1)(\mathrm{b})$.

71 Government Notice R1411 in Government Gazette 19435 of 30 October 1998. Exchange rate on 29 May $2013-1 \mathrm{ZAR}=0.125661 \mathrm{NZ} \$$ and $1 \mathrm{ZAR}=0.102218 \mathrm{USD}$.

72 Debts which are only claimable in future. Cape Town Municipality v Dunne (n 63) 744. See also Carletonville Huishoudelike Voorsieners (Edms) Bpk v Van Vuuren en ' $n$ Ander [1962] 2 SA (T) 296 and MA Greig, 'Administration Orders as Shark Nets', (2000) 117 SALJ 622, 624 for a discussion of in futuro debts as well as criticism of the exclusion thereof.

73 See in general Boraine (n 60) 217. See also Stander v Erasmus [2011] 2 SA (GNP) 320.

$74 \mathrm{~S} 74 \mathrm{~J}$ read together with ss 74E(2) and 74N. 
investigation, and a reform project was registered as Project 127. This project was suspended, pending the promulgation of the National Credit Act. However, contrary to expectations, the National Credit Act did not deal with administration orders, and on 1 May 2011 a workshop was held at the University of Pretoria where various interest groups were consulted on proposed amendments of the process provided for by section 74. The suggested amendments mainly focus on technical and procedural aspects. However, the proposal does provide for a discharge after eight years subject to specified conditions, which is certainly a step in the right direction as far as debt relief is concerned. $^{75}$

\subsection{Debt review}

One of the aims of the National Credit $\mathrm{Act}^{76}$ is to provide for debt relief through debt reorganisation in cases of over-indebtedness. ${ }^{77}$ Section 86 contains the major debt relief mechanism introduced by the Act, namely, debt review. ${ }^{78}$ However, the Act does not strive to address over-indebtedness by providing a discharge to over-indebted consumers. $^{79}$ In this regard the Supreme Court of Appeal in Collett v Firstrand Bank Ltd ${ }^{80}$ recently stated that 'the purpose of the debt review is not to relieve the consumer of his

75 See the proposed amendment to ss $74 \mathrm{U}$ and $74(1 \mathrm{~A})(\mathrm{d})$ - workshop documents on file with the authors. 7634 of 2005 .

77 See the preamble to the Act. See also Standard Bank of SA Ltd v Panayiotts [2009] 3 SA (W) 363; Firstrand Bank Ltd v Olivier [2009] 3 SA (SE) 353, 357; JM Otto, 'Over-indebtedness and Applications for Debt Review in terms of the National Credit Act: Consumers Beware! Firstrand Bank Ltd v Olivier', (2009) 21 SA Merc LJ 272.

78 S 86 should be read with the National Credit Regulations, reg 24. For a detailed discussion of the debt review process see M Roestoff and others, 'The Debt Counselling Process - Closing the Loopholes in the National Credit Act 34 of 2005', (2009) 23 PER 247, 255 et seq; C van Heerden, 'Overindebtedness and reckless credit' in JW Scholtz (ed), Guide to the National Credit Act (LexisNexis 2008-) 11-9 et seq; JM Otto and R-L Otto, The National Credit Act Explained $3^{\text {rd }}$ edn, LexisNexis 2013) 64.

79 See ss 3(g) and 3(i).

80 [2011] 4 SA (SCA) 508, 514. 
obligations but to achieve either a voluntary debt re-arrangement or a debt rearrangement by the Magistrate's Court'.

The debt review process commences with a consumer applying to a debt counsellor to be declared over-indebted and to be placed under debt review. ${ }^{81}$ Debt counsellors are registered $^{82}$ and strictly regulated by the National Credit Regulator (NCR). ${ }^{83}$ Once an application has been made, credit providers may not proceed to take steps to enforce their rights under credit agreements. ${ }^{84}$ It should, however, be noted that compulsory sequestration proceedings are not regarded as enforcement proceedings and therefore a credit provider may still apply for sequestration of the debtor's estate even where a debt review order is in force. ${ }^{85}$ Once an application for debt review has been made, parties can agree to the repayment plan or the court can order a debt restructuring. ${ }^{86}$ Ultimately the Magistrate's Court must make an order rescheduling the consumer's debt and the consumer must abide thereby. This is because even negotiated agreements will be referred to court to be sanctioned as a 'consent order' ${ }^{87}$ Debt counsellors do not receive and distribute any instalments as this function is outsourced to payment distribution agencies. ${ }^{88}$ As is the case with the administration order, debt review does not provide for a discharge, ${ }^{89}$ and no time limit is prescribed in respect of the payment plan. ${ }^{90} \mathrm{~A}$

81 S 86(1) read with National Credit Regulations, reg 24(1).

82 See National Credit Regulations, Pts A and C of Ch 2.

83 An independent statutory body established through the Act. The NCR is only subject to the Constitution of the Republic of South Africa, 1996 and the law - s 12.

$84 \mathrm{~S} 88(3)$. S 85 provides that a court may refer a credit agreement for debt review where enforcement proceedings have already commenced. See BMW Financial Services (SA) (Pty) Ltd v Donkin [2009] 6 SA (KZD) 63.

85 Naidoo v ABSA Bank Ltd [2010] 4 SA (SCA) 597 and Investec Bank Ltd v Mutemeri [2010] 1 SA (GSJ) 265.

86 Ss $86(7), 86(8)$ and 87.

87 S 138.

88 See E van Zyl, 'Registration and the consequences of non-registration' in Scholtz (n 78) 5-9.

89 S 87 read with National Credit Regulations, reg 27. See also Gordon W Johnson and Gerald E Meyerman, Insolvency Systems in South Africa - Strengthening the Regulatory Framework (a publication 
consumer can thus be bound to the plan for an excessively long period as opposed to sequestration where definite time periods are set. ${ }^{91}$ The procedure also does not make provision for the realisation of assets to service debts. ${ }^{92}$

There are no monetary limitations on the total outstanding debt, which inter alia distinguishes debt review from the administration order and allows more consumers to qualify for debt relief in terms of the National Credit Act. Secured credit agreements are furthermore included in the review, but the Act does not provide any preference regarding the repayment thereof.

If debt review is evaluated as a debt relief measure intended to serve as an alternative to sequestration, one cannot ignore its intrinsic shortcomings. Firstly, the Act only applies to credit agreements as defined in section $8 .{ }^{93}$ Debts that do not qualify as such will therefore be excluded from the debt review procedure. These may include delictual (tort) claims, clothing accounts, professional services as well as municipal accounts where no interest is charged. Another exclusion relates to agreements where the credit provider has proceeded to take steps in order to enforce the agreement. ${ }^{94}$ In this regard, the Supreme Court of Appeal in Nedbank v National Credit Regulator ${ }^{95}$ has recently

produced for review by the United States Agency for International Development for Chemonics International Inc - December 2010), 24.

90 If the process is not abandoned or terminated it seems that the issue of a clearance certificate, 'rehabilitating' the consumer, will be the only means of concluding the procedure - see ss $86(10)$ and $88 \mathrm{read}$ with National Credit Regulations, reg 27. The certificate may only be issued once the consumer has fully satisfied all the debt obligations under every credit agreement that was subject to the debt rearrangement order or agreement.

91 In this regard Johnson and Meyerman observe that the Act, despite its aims to assist over-indebted consumers, only 'perpetuates the over-indebtedness by not providing a simple debtor discharge mechanism'. Johnson and Meyerman (n 89) at 25.

92 See s 87 regarding the orders that the Magistrate's Court may make.

93 These are a credit facility, a credit transaction, a credit guarantee or a combination thereof. Usually, two elements can be identified in credit agreements, namely, a deferral of payment and a charge, interest or fee. See s 1 for the definitions of the different credit agreements. Otto and Otto (n 78) 20.

$94 \mathrm{~S} 86(2)$.

95 Nedbank Ltd $v$ The National Credit Regulator [2011] 3 SA (SCA) 581, 590. 
held, in our view incorrectly, ${ }^{96}$ that the provisions of section $86(2)^{97}$ would bar the consumer from including that specific agreement in the debt review procedure as soon as a section 129(1)(a) notice ${ }^{98}$ has been delivered in respect of that specific credit agreement. A credit provider will thus in effect be able to prevent a consumer from including a particular credit agreement in the debt review by merely forwarding a section 129 notice to such consumer once he or she is in default.

\subsection{Insolvency law reform initiatives}

The Law Reform Commission has proposed that provision be made for a preliquidation ${ }^{99}$ composition $^{100}$ with creditors by inserting a new section, section $74 \mathrm{X}$, in the Magistrates' Courts Act. ${ }^{101}$ This proposal has also been included in the report of the Centre for Advanced Corporate and Insolvency Law (SACIL) at the University of Pretoria $^{102}$ and in the latest version of the Insolvency Bill. ${ }^{103}$ In the latter two documents it is envisaged that the proposed measure should be included in the new unified Insolven-

96 Commentators interpret s 86(2) differently. See eg A Boraine and S Renke, 'Some Practical and Comparative Aspects of the Cancellation of Instalment Agreements in terms of the National Credit Act 34 of 2005', (2008) 41 De Jure 1, 9 n186; Danie Van Loggerenberg, Leon Dicker and Jacques Malan, 'Aspects of Debt Enforcement under the National Credit Act', (2008) January/February De Rebus 40, 40; M Roestoff and others (n 78) 260; Hermie Coetzee, 'The Impact of the NCA on Civil Procedural Aspects Relating to Debt Enforcement' (unpublished LLM by research, University of Pretoria 2010), 86.

$97 \mathrm{~S} 86(2)$ provides that 'an application in terms of this section may not be made in respect of, and does not apply to, a particular credit agreement if, at the time of that application, the credit provider under that credit agreement has proceeded to take the steps contemplated in section 129 to enforce that agreement'.

98 The s 129(1)(a) notice is a letter which a credit provider must send to a defaulting consumer before such credit provider may commence legal proceedings to enforce the agreement.

99 The Insolvency Bill uses the term 'liquidation' when referring to both liquidation of juristic persons and sequestration of natural persons.

100 The title of the proposed provision is confusing as it could mistakenly be interpreted to require a composition as a pre-condition for insolvency proceedings.

101 See 2000 Explanatory Memorandum and 2000 Insolvency Bill schedule 4. See M Roestoff and L Jacobs, 'Statutêre Akkoord voor Likwidasie: 'n Toereikende Skuldenaar Remedie', (1997) 30 De Jure 189, 204 and M Roestoff, 'Eenvormige Insolvensiewetgewing in Suid-Afrika: Moet die Administrasiebevel Ingesluit word?' (2000) 33 De Jure 127, 131 et seq for a discussion of the proposal in the 2000 Insolvency Bill.

102 Final Report Containing Proposals on a Unified Insolvency Act (January 2000).

1032010 Insolvency Bill, cl 118. 
cy Act and not the Magistrates' Courts Act. The proposed measure is supposed to afford debt relief to debtors who are unable to show an advantage to creditors and are therefore excluded from the liquidation process. ${ }^{104}$

The 2010 Insolvency Bill provides for a binding composition between a debtor and creditors if it is accepted by the required majority in number and two-thirds in value of the concurrent creditors who vote on the composition. ${ }^{105}$ The composition is supervised by the court and provision is made for an investigation into the affairs of the debtor. ${ }^{106}$ The claims or rights of secured or preferent creditors shall only be subject to the composition if they consented thereto in writing. After the court has certified that the composition is accepted it will be binding on all creditors who have been informed of the hearing or appeared at the hearing. ${ }^{107}$ The composition does not constitute a bar to the liquidation of the debtor's estate. ${ }^{108}$ If the required majority does not accept the composition and the debtor is unable to pay substantially more than what is offered in the composition, the court must declare that the proceedings have ceased and that the debtor is in the position that he or she was in prior to commencement thereof. Alternatively, the court must determine whether or not section 74 of the Magistrates' Courts Act can be applied to the debtor and, if so, apply the provisions accordingly and within the discretion of the presiding officer. ${ }^{109}$

\footnotetext{
104 See 2000 Explanatory Memorandum, 5.

$105 \mathrm{Cl} 118(17)$.

${ }^{106} \mathrm{Cl} 118(10)(\mathrm{e})$.

${ }^{107} \mathrm{Cl} 118(17)$.

${ }^{108} \mathrm{Cl} 118(21)$.

109 See sub-cls 118(22)(a) and 118(22)(b). The Commission's proposal in the 2000 Insolvency Bill afforded the debtor the option to convert to liquidation and rehabilitation ito the proposed Insolvency Act in instances where the composition was not accepted by the required majority - see the discussion of this proposal by Roestoff and Jacobs (n 101) 207 et seq.
} 


\subsection{Analysis}

From the above discussion ${ }^{110}$ it should be clear that current South African procedures do not provide adequate debt relief to consumers. Because sequestration is an expensive procedure to follow and because of the advantage for creditors requirement, sequestration will in many instances not provide an outcome to debtors, seeking debt relief. For the same reasons sequestration would clearly not provide an outcome to NINA debtors seeking debt relief.

As regards the administration procedure in terms of the Magistrates' Courts Act, it should be clear that it is of limited scope, since it is only available to debtors whose claims do not exceed R50 000. The procedure furthermore does not provide for a discharge of debts, because the administration order only lapses once the cost of administration and the listed creditors have been paid in full. The alternative remedy of debt review in terms of the National Credit Act is also of limited scope as it only provides debt relief in respect of debt which qualifies as 'credit agreements' in terms of the National Credit Act. The Act furthermore does not provide for the possibility that the court could force a discharge of a part of the consumer's debt obligations on the debtor's creditors. The processes of administration and debt review will therefore not provide debt relief to debtors who do not have sufficient income to repay their debt and will clearly not provide an outcome to NINA debtors.

As regards insolvency law reform initiatives and the proposed pre-liquidation composition with creditors ${ }^{111}$ it is submitted that the main deficiency of this proposed measure

\footnotetext{
${ }^{110}$ Paras 3.2-3.4.

111 See para 3.5 .
} 
as a viable option for a debtor seeking debt relief is that it would not, in its current format, provide such a debtor with a discharge if the composition is not accepted by the required majority of creditors. ${ }^{112}$ For NINA debtors it will therefore clearly not provide an outcome as there will probably be nothing that can be offered to creditors.

\section{New Zealand}

\subsection{Introduction}

The New Zealand Insolvency Act ${ }^{113}$ makes provision for bankruptcy as well as alternative measures ${ }^{114}$ in the form of proposals, ${ }^{115}$ summary instalment orders, ${ }^{116}$ and the no asset procedure. ${ }^{117}$ New Zealand was the first jurisdiction to specifically provide for the NINA debtor. The following discussion briefly sets out the bankruptcy- and alternative procedures where after the no asset procedure is discussed in more detail. It is important to view the system holistically to understand where and how the no asset procedure fits into the broader personal insolvency law.

\subsection{Bankruptcy}

Bankruptcy may be applied for by creditors or the debtor him- or herself. A creditor applies to court ${ }^{118}$ and the debtor to the assignee. ${ }^{119}$ All provable debt is included ${ }^{120}$ in the

\footnotetext{
${ }^{112}$ As pointed out above the court may in such a case apply s 74 of the Magistrates' Courts Act which procedure does not provide for any discharge of debt obligations.

113 Public Act 2006 No 55 (NZ).

${ }^{114}$ S 8. See Mike Josling, 'Alternatives to bankruptcy' in Paul Heath and Michael Whale (eds), Insolvency Law in New Zealand (LexisNexis 2011) 238 to 265 for a discussion on alternatives to bankruptcy.

${ }^{115}$ Pt 5 sub-pt 2, ss 325-339.

${ }^{116}$ Pt 5 sub-pt 3, ss 340-360.

${ }^{117}$ Pt 5 sub-pt 4, ss 361-377B.

${ }^{118}$ Ss $13-15$ and 36.

${ }^{119}$ Ss 45-49. The assignee is part of the Insolvency and Trustee Service, a unit in the Business Services Branch of the Ministry of Economic Development. See in general Pt 7 sub-pt 1 - the Assignee. The role of the assignee is separate from that of the courts which are administrated through the Ministry of Justice.

${ }^{120}$ Ss 231 and 232.
} 
procedure and is generally automatically discharged after a period of three years. ${ }^{121}$ Provable debts are those which the bankrupt owes at time of adjudication or thereafter but before discharge. ${ }^{122}$ Secured debt, however, receives special treatment. Secured creditors have a number of options at their disposal. ${ }^{123}$ They can realise the property, ${ }^{124}$ value the property and prove in bankruptcy as an unsecured creditor for the balance, ${ }^{125}$ or surrender the property to the assignee and prove in bankruptcy as an unsecured creditor for the whole of the outstanding amount. ${ }^{126}$ On adjudication, all property belonging to the bankrupt vests in the assignee. ${ }^{127}$ There are substantial personal restrictions on a bankrupt such as a restriction on entering business without the consent of the assignee ${ }^{128}$ or to travel overseas under certain circumstances. ${ }^{129}$

In New Zealand, the role of the assignee is expanded under the 2006 Act and bankruptcy is now mostly an administrative procedure. The office of the assignee nowadays provides for a state-funded 'one stop shop' for insolvent debtors. Under the new Act, the assignee assumes responsibility for various matters that previously fell within the jurisdiction of the courts. ${ }^{130}$ However, Telfer notes that there might potentially be conflicts

${ }^{121} \mathrm{~S} 304(2)$ lists debts that are provable, but from which the bankrupt is not released on discharge. See Pt 4 sub-pt 1 relating to discharge from bankruptcy.

${ }^{122} \mathrm{~S}$ 232(1). S 232(2) sets out debts that are not regarded as provable debts in bankruptcy.

${ }^{123}$ S 243. See also Jim Guest, 'Introduction: Personal Insolvency' in Kiri O'Hagan and Shuai Yu (eds) Heath and Whale: Insolvency Law in New Zealand (LexisNexis 2011) 114.

${ }^{124}$ If permitted to do so $-\mathrm{s} 243(1)(\mathrm{a})$.

${ }^{125} \mathrm{~S} \mathrm{243(1)(b).}$

${ }^{126} \mathrm{~S} 243(1)(\mathrm{c})$.

${ }^{127} \mathrm{~S} 101$. Except those exempted in terms of s 158.

${ }^{128} \mathrm{~S} 149$.

${ }^{129} \mathrm{~S} 426$.

${ }^{130}$ See Thomas GW Telfer, 'New Zealand Bankruptcy Law Reform: The New Role of the Official Assignee and the Prospects for a No-Asset Regime' in Johanna Niemi-Kiesiläinen, Iain Ramsay and William Whitford (eds), Consumer Bankruptcy in Global Perspective (Hart Publishing 2003) 248. 
of interest as the "[a]ssignee will play the role of fact finder, adjudicator and creditor representative, as well as a counsellor to the debtor'. ${ }^{131}$

\subsection{Proposals}

As an alternative to bankruptcy a person who is unable to pay his or her debts ${ }^{132}$ may make a proposal to creditors for the payment or satisfaction of the insolvent's debts. ${ }^{133}$ Such proposals may include various schemes, ${ }^{134}$ must be in the prescribed form accompanied by a statement of affairs ${ }^{135}$ and must be filed at court. ${ }^{136}$ The proposal will name a trustee that becomes the provisional trustee and who must call a meeting of creditors to vote on the proposal. ${ }^{137}$ Three-quarters in value and the majority in number of creditors must accept the proposal whereafter it must be approved by a court. ${ }^{138}$ The court must hear objections by creditors before approving the proposal. ${ }^{139}$ If the court approves the proposal, it binds all creditors whose debts are provable and are affected and creditors may not take enforcement steps without the court's permission. ${ }^{140}$ Even though creditors may not apply for the debtor's adjudication without the court's consent whilst the proposal remains in force, ${ }^{141}$ the insolvent may file such an application which will effectively cancel the proposal. ${ }^{142}$ Once the proposal is approved, the insolvent must put the proposal into effect ${ }^{143}$ and the trustee must administer property in accordance there-

\footnotetext{
131 ibid. See also 256-60.

${ }^{132} \mathrm{~S} 325(2)$ determines that debt has the same meaning as provable debts in bankruptcy.

${ }^{133}$ Ss 325 and 326.

${ }^{134}$ The proposal may be an offer to pay debts in instalments or to compromise the debts at less than 100 cents in the dollar - s 326(2).

${ }^{135} \mathrm{~S} 327$.

${ }^{136} \mathrm{~S} 328$.

${ }^{137}$ Ss $329-331$.

${ }^{138}$ Ss 331-333.

${ }^{139} \mathrm{~S} 333(2)$.

${ }^{140}$ Ss 334-335.

${ }^{141}$ S 335(2). See also s 339.

${ }^{142} \mathrm{~S} 339(5)$.

${ }^{143} \mathrm{~S} 336$.
} 
with and further generally give effect thereto. ${ }^{144}$ The proposal may be varied or cancelled by the court under certain circumstances. ${ }^{145}$

Brown points out that the major disadvantages of this procedure are that it requires a significant majority of creditors' consent, that it involves a court application and that there is no moratorium prior to court approval. He further comments that 'the nature of proposals acceptable to creditors means that they would not be suitable for most debtors with no or few assets'. ${ }^{146}$

\subsection{Summary instalment orders}

The second alternative personal insolvency procedure takes the form of a summary instalment order. The debtor or a creditor, with the debtor's consent, may apply to the assignee for such an order. ${ }^{147}$ It is an order by the assignee and takes the form of a repayment plan whereby the assignee may order the debtor to pay debts in instalments (or otherwise), either in full or to the extent that it is considered practical in the circumstances. ${ }^{148}$ The procedure generally is for a period of 3 years and may be extended to 5 years under special circumstances. ${ }^{149}$ Application should take place in the prescribed form and if the debtor is the applicant, should include extensive information, such as whether the debtor proposes to pay creditors in full or otherwise, details pertaining to the payment, the proposed supervisor or reasons why such supervision will not be necessary as well as particulars relating to the debtor, his or her property, creditors, debts,

\footnotetext{
${ }^{144}$ S 337.

145 S 339.

146 David Brown, 'The Financial Health Benefits of a Quick "NAP" - New Zealand's Solution to Consumer Insolvency?', (INSOL Conference Academic Programme, Vancouver, June 2009) 8.

147 S 341.

${ }^{148} \mathrm{~S} 340$.

${ }^{149}$ S 349.
} 
earnings and employment. ${ }^{150}$ The assignee may make the order if the total unsecured debt, excluding student loans, is NZ\$40 000 or less and the debtor cannot immediately repay the debt. ${ }^{151}$ The assignee may make additional orders regarding future earnings, the disposal of goods and the powers of the appointed supervisor - if a supervisor was appointed. ${ }^{152}$ The supervisor must supervise the debtor's compliance with the order ${ }^{153}$ and may charge the debtor for his or her services. ${ }^{154} \mathrm{He}$ or she must provide the assignee with documents if so requested and the appointment may be terminated by the assignee under certain circumstances. ${ }^{155}$ Once the order has been granted, a creditor may not commence or continue enforcement proceedings unless the permission of the assignee was obtained or the debtor is in default under the order. ${ }^{156}$ The debtor's name will be included in a public register of debtors subject to the order. ${ }^{157}$ Money paid by the debtor will be distributed firstly to pay administration costs, then that of the assignee and thirdly debts in accordance with the order. ${ }^{158}$ Once these liabilities have been paid in full, the debtor is discharged from unsecured debts to which the order relates. ${ }^{159}$ There is a presumption that a debtor who defaults under the order has been able to pay and has refused or neglected to do so. Once a debtor is in default, enforcement proceed-

${ }^{150} \mathrm{~S} 342$.

$151 \mathrm{~S} 343$.

152 S 344.

153 According to s 353, the supervisor must give notice of the order to creditors.

154 Ss 345 and 346. The fees may be regulated by the Governor-General. Insolvency (Personal Insolvency) Regulations 2007, reg 64 provides that the supervisor may charge the debtor $7.5 \%$ of the value of the debtor's assets recovered by the supervisor.

155 Ss 347-348.

$156 \mathrm{~S} 352$.

${ }^{157} \mathrm{~S} 354$. The assignee must maintain a register of persons subject to a current order. S 55 provides that an order is not current when discharged or instalments have been paid in accordance with the order.

${ }^{158} \mathrm{~S}$ 358. Insolvency (Personal Insolvency) Regulations 2007, reg 18(2) provides that the assignee's rate of remuneration is $2.5 \%$ of the value of the debtor's assets recovered by the supervisor.

159 S 358(2). 
ings may begin or continue. ${ }^{160}$ The debtor commits an offence if he or she incurs a liability of more than NZ\$1000 without proper prior disclosure. ${ }^{161}$

\subsection{The No Asset Procedure}

\subsubsection{Objectives of procedure}

The no asset procedure is provided for by part 5 subparagraph 4 of the Insolvency Act which consists of sections 361 to $377 \mathrm{~B}$. It offers a debt relief procedure to a debtor 'who has no realisable assets' and 'does not have the means of repaying any amount towards those debts'. ${ }^{162}$

Josling summarises the policy behind the procedure as follows: ${ }^{163}$

The basic policy behind the procedure is that the full bankruptcy process, with its duration, and consequential restrictions, is no longer appropriate to small debtors. These debtors, it is said, are typically always struggling to pay their debts, and are usually pushed into bankruptcy by some unfortunate event. In bankruptcy a dividend is hardly ever paid to creditors. Thus the justifications combine economic, humanitarian, and practical rationales.

It seems that one of the major driving forces behind the introduction of the no asset procedure was the need to channel assetless insolvents to a more appropriate debt relief measure, as they previously mainly opted for bankruptcy which is not suited to these

\footnotetext{
${ }^{160}$ S 359.

${ }^{161} \mathrm{~S} 360$.

${ }^{162} \mathrm{~S} 363$.

${ }^{163}$ See Mike Josling, 'Introduction' in Kiri O’Hagan and Shuai Yu (n 114) 7 et seq.
} 
estates. ${ }^{164}$ Guest notes that the reform appears to distinguish between those who became insolvent due to irresponsible trading and those, usually consumers, who become overindebted to such a degree that public interest calls for a fresh start and that the more punitive measures in the Act will only apply to the so called 'irresponsible'. ${ }^{165}$ The author also refers to the belief that the no asset procedure will have a considerably reduced amount of social stigma attached to it. ${ }^{166}$

\subsubsection{Entry requirements}

Given the fact that the no asset procedure remains for a 12-month period, as opposed to the three-year period under bankruptcy, Parliament has set up strict entry criteria in order to prevent abuse. ${ }^{167}$

A debtor can secure entry to the procedure on application to the assignee by completing and filing an application form as well as a statement of affairs. ${ }^{168}$ Entry criteria can be divided into criteria relating to the debtor's objective financial position and those relating to his or her conduct. The assignee may admit or refuse the debtor depending on its satisfaction on whether the criteria have been met on reasonable grounds. ${ }^{169}$ The financial requirements are that the debtor has no realisable assets ${ }^{170}$ and that the total debt is

\footnotetext{
${ }^{164}$ See David Brown and Thomas GW Telfer, Personal and Corporate Insolvency Legislation: Guide and Commentary to the 2006 Amendments ( $2^{\text {nd }}$ edn, LexisNexis NZ Limited 2013) 37.

${ }^{165}$ See Jim Guest, 'Introduction: Personal Insolvency' in Kiri O'Hagan and Shuai Yu (n 123) 14.

${ }^{166}$ See Jim Guest, 'Introduction: Personal Insolvency' in in Kiri O'Hagan and Shuai Yu (n 123) 18.

${ }^{167}$ See Brown and Telfer (n 164) 38.

${ }^{168}$ Ss 362(1) and 362(2). Refer also to Insolvency (Personal Insolvency) Regulations 2007, reg 65.

${ }^{169} \mathrm{~S} 363(1)$.

${ }^{170} \mathrm{~S} \mathrm{363(1)(a)} \mathrm{-} \mathrm{that} \mathrm{is} \mathrm{the} \mathrm{requirement} \mathrm{relating} \mathrm{to} \mathrm{the} \mathrm{debtor's} \mathrm{solvency} \mathrm{position.} \mathrm{S} \mathrm{363(2)} \mathrm{provides} \mathrm{that}$ realisable assets do not include those assets that a bankrupt is allowed to retain under s 158, but does, however, include assets that the assignee may recover if the debtor were adjudicated bankrupt as well as if the irregular transaction provisions in terms of sub-pt 7 of Pt 4 applied.
} 
not lower than NZ\$1 000 and not more than NZ\$40 000. ${ }^{171}$ The debtor must further not have the means of repaying any amount towards such debts. ${ }^{172}$ Further criteria are that the debtor should not previously have been admitted to the no asset procedure ${ }^{173}$ or been adjudicated bankrupt. ${ }^{174}$ The debtor is disqualified from entry and the assignee must not admit a debtor to the no asset procedure:

a. if the debtor has concealed assets with the intention to defraud creditors; ${ }^{175}$

b. if the debtor has engaged in conduct that would constitute an offence under the Act if the debtor were adjudicated bankrupt; ${ }^{176}$

c. if the debtor has incurred debt or debts whilst knowing that he or she does not have the means to repay such debts; ${ }^{177}$ or

d. where a creditor intends to apply for the debtor's adjudication as a bankrupt and there is a likelihood that the outcome will be materially better than under the no asset procedure. $^{178}$

${ }^{171}$ S 363(1)(d). S 363(3) provides that these amounts may be altered to take cognisance of the Consumer Price Index.

${ }^{172} \mathrm{~S} 363(1)(\mathrm{e})$. Such determination is made under a prescribed means test. See also Insolvency (Personal Insolvency) Regulations 2007, reg 65 and reg 66 read with reg 6. Reg 66 provides that: The prescribed means test for the purposes of section 363(1)(e) is whether, taking into account the income of the debtor personally and that of any relative with whom the debtor lives, the debtor has a surplus of money after paying the household's usual and reasonable living expenses.

${ }^{173} \mathrm{~S} 363(1)(\mathrm{b})$.

${ }_{174}^{174}$ S 363(1)(c).

${ }^{175}$ S 364(a).

${ }^{176} \mathrm{~S} 364(\mathrm{~b})$.

${ }^{177}$ S 364(c). See Brown and Telfer (n 164) 41 who express the view that this exclusion may be problematic in that the assignee may have difficulty in applying the disqualification where for instance a debtor in dire circumstances was forced to take out a loan which he or she honestly believed could be repaid in future even though he or she does not have the means to repay immediately.

${ }^{178}$ S 364(d). 
Once a debtor has applied for entry, the assignee must, as soon as practicable, send a summary of the debtor's assets and liabilities to all known creditors. ${ }^{179}$ A debtor must not obtain further credit after he or she has applied for the procedure. ${ }^{180}$

A debtor is admitted to the procedure when the assignee sends a written notice to such effect to the debtor. The assignee must notify creditors and advertise that the debtor has been admitted to the no asset procedure. ${ }^{181}$ The assignee must maintain a public register of persons admitted to and discharged from the procedure. ${ }^{182}$

\subsubsection{Effect of Entry}

Creditors are affected by the no asset procedure as there is an effective moratorium on the enforcement of debt. A creditor may not begin or continue to recover or enforce debt once a debtor has been admitted to the procedure. Debts that may not be enforced are those which were owed on the date of application and would be provable under bankruptcy. ${ }^{183}$ However, this procedure does not apply to maintenance orders, ${ }^{184}$ amounts payable under the Child Support Act ${ }^{185}$ and student loans. ${ }^{186}$

The debtor has a duty to comply with reasonable requests by the assignee to provide assistance, documents and other necessary information for applying the procedure to the

\footnotetext{
${ }^{179} \mathrm{~S} 365$.

${ }^{180}$ S 366.

${ }^{181}$ S 367. See also Insolvency (Personal Insolvency) Regulations 2007, reg 67.

${ }^{182}$ S 368 and pt 7, sub-pt 5. See also 448(3) and s 448(4).

${ }^{183}$ Secured debts are generally excluded from bankruptcy and therefore also from the no asset procedure, s 243.

${ }^{184}$ Under the Family Proceedings Act 1980.

${ }^{185}$ Child Support Act 1991.

${ }^{186} \mathrm{~S} 369$. The fact that student loans are enforceable under the no asset procedure stands in contrast to straight bankruptcy where student loans are discharged. Compare ss 369(2)(c) and 304.
} 
debtor. The latter must notify the assignee as soon as possible of a change in circumstances that would allow the debtor to repay an amount towards the debts under the procedure and must not obtain credit of more than NZ\$1 000 without first informing the credit provider that he or she is subject to the no asset procedure. ${ }^{187}$ If the debtor obtains such credit without the necessary disclosure, the debtor commits an offence which is punishable by imprisonment for a maximum term of one year or a maximum fine of NZ\$5 000 or both. ${ }^{188}$

\subsubsection{Termination and Discharge}

Termination of the procedure, except termination by discharge, lifts the moratorium on the enforceability of debt. The debtor will also be liable to pay penalties and interest that may have accrued whilst the procedure was in force. ${ }^{189}$

The procedure can be terminated upon the happening of various events, for example by and under the discretion of the assignee, the debtor's discharge, the debtor's application for his or her own adjudication or the application for adjudication by a credit provider that is entitled to do so. ${ }^{190}$ The assignee may terminate the no asset procedure where the debtor was wrongly admitted (for example where the debtor concealed assets or misled the assignee) or the assignee is satisfied that the financial circumstances have changed

\footnotetext{
${ }^{187}$ S 370.

${ }^{188}$ S 371.

${ }^{189} \mathrm{~S} 375$.

${ }^{190}$ S 372 . For instance, a credit provider may apply for adjudication where the creditor's debt remains enforceable under a student loan. See S 372(d) read together with s 369(2).
} 
to such an extent that the debtor can repay an amount towards the debt. Termination by the assignee takes place by sending a notice to the debtor and becomes effective when the notice is sent, irrespective of whether it is received by the debtor. The assignee must thereafter also notify known creditors. ${ }^{191}$ If the assignee terminated the participation on the ground that the debtor has concealed assets or misled the assignee, the court, on application by the assignee, may make a preservation $\operatorname{order}^{192}$ on terms and conditions that the court sees fit, pending an application of the debtor's adjudication. ${ }^{193}$ A creditor may apply to the assignee for termination where the creditor objects on grounds that the debtor did not meet the entry requirements or where there are reasonable grounds for the assignee to conclude that the debtor was disqualified on grounds in terms of section 364. ${ }^{194}$ The first three grounds for disqualification in terms of section 364 relate to dishonesty, while the fourth ground refers to the situation where a creditor intends to apply for the debtor's adjudication as a bankrupt and the outcome would likely be better under bankruptcy than under the no asset procedure. It is therefore clear that this avenue will still be available to creditors after the no asset procedure has commenced. If a creditor discovers that bankruptcy may be more beneficial, the creditor may apply to the assignee for termination and apply for the debtor's adjudication as a bankrupt.

If the procedure is not terminated on the grounds as set out above, the debtor will automatically be discharged from the procedure 12 months after the date on which the debtor was admitted thereto. However, such discharge will not take place where the assignee

\footnotetext{
${ }^{191}$ S 373. See also Insolvency (Personal Insolvency) Regulations 2007, reg 68 regarding the assignee's notice to the debtor.

${ }^{192}$ To, for the benefit of creditors, protect or preserve property in the interim. See Jim Guest, 'Process for Procuring Bankruptcy' in Kiri O’Hagan and Shuai Yu (n 123) 52.

${ }^{193}$ S 374.

${ }^{194}$ S 376.
} 
is satisfied that the 12-month period should be extended to appropriately consider whether the procedure should be terminated and the assignee has sent a notice of deferral to the debtor. The notice ${ }^{195}$ must indicate the alternative date for automatic discharge, which must not be more than 25 working days after expiry of the 12 -month period. The debtor will be automatically discharged on the date stated in the notice. ${ }^{196}$ The assignee must also send a deferral notice to known creditors. ${ }^{197}$

Upon discharge, the debtor's debts that became unenforceable are cancelled and the debtor is not liable to pay any part thereof. This includes penalties and interest. The discharge does not apply to debt or liability incurred by fraud or fraudulent breach of trust or for which the debtor has obtained forbearance through fraud. These debts and liabilities become enforceable on discharge and the debtor is also liable for penalties and interest. ${ }^{198}$ Finally, the discharge relates to the debtor only and not to business partners, co-trustees, guarantors or any person jointly bound or who had made any contract with the discharged debtor. ${ }^{199}$

Telfer comments that the difference between the 3-year discharge period in bankruptcy and the 12-month period in the no asset procedure may lead to possible abuse of the no asset procedure in order to 'fast track' the discharge. Clearly, the bigger the inconsistency between the two procedures, the greater the need for resources to ensure that the sys-

\footnotetext{
195 The notice is effective whether the debtor receives it or not $-\mathrm{s} 377$ (4).

196 The notice may be revoked, in which case the debtor is automatically discharged on expiry of the 12month period - if the notice was revoked prior to that date. If that is not the case, the debtor will be discharged on the date of revocation.

${ }^{197}$ S 377.

${ }^{198}$ S 377A. This section was inserted by s 10(2) of the Insolvency Amendment Act 2009.

${ }^{199}$ S 377B. This section was inserted by s11 of the Insolvency Amendment Act 2009.
} 
tem is not misused. ${ }^{200}$ In this regard the Act contains strict provisions to prevent such abuse in some instances by requiring significant investigation by the assignee.

\section{Lessons, recommendations and conclusions}

It seems that one of the major driving forces behind the introduction of the no asset procedure in New Zealand was the need to channel assetless insolvents to a more appropriate debt relief measure, as they previously mainly opted for bankruptcy which, due to its duration and consequential restrictions, is not suited to such estates. ${ }^{201}$ South Africa, in contrast, does not have any procedure available to such consumers. Moreover, the NINA debtors in South Africa are in a much worse position than the NINA debtor in New Zealand prior to the introduction of the no asset procedure. New Zealand NINA debtors had an option in the form of bankruptcy which could have resulted in a fresh start as the procedure does not contain an advantage for creditors requirement. In South Africa, NINA debtors will not qualify for straight bankruptcy (sequestration) under the Insolvency Act as they will not be able to prove an advantage to creditors. ${ }^{202}$ They furthermore will not qualify for debt review under the National Credit Act as they will not be able to make viable proposals to service their debt. ${ }^{203}$ In some instances they will also not be able to qualify for administration under the Magistrates' Courts Act as their debt might be more than R50 000. ${ }^{204}$ In practice, creditors will obtain judgment against such debtors and if they are employed in the formal sector, an emoluments attachment order

\footnotetext{
200 See Thomas GW Telfer, 'New Zealand Bankruptcy Law Reform: The New Role of the Official Assignee and the Prospects for a No-Asset Regime' in Johanna Niemi-Kiesiläinen, Iain Ramsay and William Whitford (n 130) 265-266.

201 See para 4.4.1.

202 See paras 3.2 and 3.6 .

203 See paras 3.4 and 3.6 .

${ }^{204}$ See paras 3.3 and 3.6.
} 
will be obtained. ${ }^{205}$ Furthermore, as these debtors do not have any procedural remedy at their disposal, coupled with the possibility of a judgment and an almost definite emoluments attachment order, ${ }^{206}$ the dual economy is re-enforced, which contributes to keeping the 'poor' in a state of poverty. Thus, just as New Zealand was in need of a more appropriate measure, South Africa is in desperate need of a procedure to cater for NINA debtors.

The reasons for the recent reform of the New Zealand insolvency system and the introduction of the no asset procedure are important when considering the introduction of a no asset procedure in South Africa. South Africa can learn from New Zealand in that it is not sensible to put a no asset debtor through a costly bankruptcy procedure. As the sequestration process is an expensive one to follow, ${ }^{207}$ we believe that it should only be resorted to if it is cost effective to do so, that is, if the proceeds of the free residue would be sufficient to cover the costs of sequestration and to provide a non-negligible dividend to creditors. The advantage for creditors requirement fulfils an important function in this regard and it is submitted that the solution to the NINA cases should rather be found in an alternative measure.

When considering the current alternative measures in South Africa, one cannot ignore their flaws and shortcomings. ${ }^{208}$ It should be clear that a holistic review of the current alternative measures is necessary. Only in the context of a broader, all-inclusive review, will it be possible to devise the best possible solution for NINA debtors. It is, however,

\footnotetext{
${ }^{205}$ See para 2.

206 ibid.

207 See para 3.2.

${ }^{208}$ See paras 3.3 and 3.4.
} 
submitted that it is not necessary to redraft the entire content and structure of the current measures in order to reach these objectives. Existing alternative procedures should rather be combined, further developed and added to in order to provide a more accessible, effective and non-discriminate system. ${ }^{209}$ We believe that a combination of the best elements of the current two statutory repayment measures, debt review and administration, will go a long way towards improving the system. All consumers who can at least pay something towards their debts should have access to the reformed repayment procedure. The procedure should make provision for a discharge and maximum time frames. ${ }^{210}$ Judgment debt should also be included. At present, judgment debt forms part of both the sequestration and administration procedures, but for reasons unknown, cannot be included under debt review. However, secured debt should not form part of the reformed repayment procedure. Creditors' opposition to debt review applications are mainly due to the fact that such creditors are locked into the procedure and can therefore not rely on their securities for satisfaction of the outstanding amounts. The inclusion of secured debt can, as is the case under the National Credit Act at present, unnecessarily complicate the process, increase the total costs of the procedure and annul the very notion of security. Though it is somewhat incomprehensible to contemplate absolutely no court involvement within the South African insolvency regime at present, it is submitted that investigation into at least the reduction of court involvement should be undertaken. ${ }^{211}$ However, this will only be possible once the best suited regulator ${ }^{212}$ for the re-

\footnotetext{
209 André Boraine, Corlia van Heerden and Melanie Roestoff, ‘A Comparison between formal debt administration and debt review - the pros and cons of these measures and suggestions for law reform (Part 1)' (2012) 45 De Jure 62 and '(Part 2)’ (2012) De Jure 254.

210 The New Zealand Summary Instalment Order serves as an example. See para 4.4.

${ }^{211}$ New Zealand has the minimum court involvement. See para 4.

${ }^{212}$ As indicted, current regulators are the Master of the High Court and the National Credit Regulator.
} 
formed repayment procedure has been established and its functions have been expanded which in itself calls for intensive further research.

Even if the suggested reform does take place, neither sequestration nor the suggested reformed repayment plan, will be specifically suited to the needs of NINA debtors. The proposed pre-liquidation composition ${ }^{213}$ will also not be an option for the NINA debtor as there will probably be nothing that can be offered to creditors. ${ }^{214}$ We therefore support the idea of introducing a separate procedure for the NINA debtors in South Africa as is the case in New Zealand. It is acknowledged that the two jurisdictions differ in their socio-economic and cultural backgrounds and that a foreign system should not be wholly transplanted without taking cognisance of these factors. However, it is submitted that the need for a no asset procedure is even more pressing in the context of a developing economy. As was stated previously, not providing a measure for this relegated group sustains the dualism in the South African economy by systemically contributing to keeping the 'poor' in a state of poverty. The authors are also of the opinion that such exclusion infringes the basic constitutional right of equality under the law. ${ }^{215}$ It is submitted that the no asset procedure in New Zealand offers an uncomplicated procedure which simplicity is especially attractive from a developing country's perspective. It is suggested that this procedure may serve as a basic guide in devising a customised procedure for the South African NINA debtor.

\footnotetext{
${ }^{213}$ See paras 3.5 and 3.6.

${ }^{214}$ See the criticism of Brown i.r.o. New Zealand Proposals discussed in para 4.3.

${ }^{215}$ S 9(1) of the South African Constitution, 1996.
} 
In considering a separate no asset procedure in South Africa, we are in agreement with Telfer, ${ }^{216}$ that the larger the inconsistency between procedures, the greater caution and need for resources to ensure that the system is not misused. Our suggestion is therefore that, should South Africa consider a no asset procedure, the procedure should as far as practically and reasonably possible be akin to that under the sequestration and the reformed repayment procedure.

Whereas the majority of the insolvency procedures in New Zealand are now administrative in nature and are channelled through the office of the assignee, ${ }^{217}$ that seems to be strategically well positioned for this task, the South African position is more complicated due to the multiplicity of existing regulators. These regulators also resorts under different government departments, ${ }^{218}$ which further complicates matters. It is submitted that further investigation and research are necessary in order to establish the most suitable government department and consequently, regulator for the proposed no asset procedure.

When contemplating the form and structure of a no asset procedure in South Africa, we suggest the following:

a) a maximum time frame similar to that under the reformed repayment measure, coupled with a discharge;

\footnotetext{
${ }^{216}$ See Thomas GW Telfer, 'New Zealand Bankruptcy Law Reform: The New Role of the Official Assignee and the Prospects for a No-Asset Regime' in Johanna Niemi-Kiesiläinen, Iain Ramsay and William Whitford (n 130) 265-266.

${ }^{217}$ See para 4.2.

${ }^{218}$ The Master of the High Court falls under the Department of Justice and the National Credit Regulator under the Department of Trade and Industry.
} 
b) the inclusion of all debts except for secured debt, as is the case in New Zealand;

c) the inclusion of debts where individual debt enforcement measures have commenced; and

d) as NINA debtors will not be able to pay intermediaries for the administration of their estates, we suggest an investigation into whether the Master of the High Court or the National Credit Regulator may fulfil this function.

When considering the introduction of a no asset procedure, the most important consideration is the possible impact on the broader South African community and economy. Although it is true that the system will be abused by some, possible abuse is not an excuse for not providing equal treatment (as far as possible) to all over-indebted or insolvent South African consumers. Safety measures ${ }^{219}$ should be built into the procedure to minimise possible abuse, but this should not frustrate the objectives of a cost effective measure. Even though introducing a no asset measure will have an impact on the economy, it would be more expensive to keep these consumers in their desperate situations, thereby totally excluding them from the formal sector and economy.

No legislative provision will be able to alleviate poverty. However, we believe that the system can keep debtors in a state of poverty and further entrench the dichotomy between the 'haves' and the 'have nots'. By removing these obstacles from the system and

\footnotetext{
${ }^{219}$ See eg the entry requirements iro the New Zealand no asset procedure (para 4.5.2) and the provisions in respect of the discharge and termination of the procedure (para 4.5.4). The World Bank suggests the careful design and implementation of suitable access requirements for access to a procedure as well as for a discharge. Proper access requirements combined with cautious monitoring by administrators and creditors will minimise moral hazard and debtor fraud. See The World Bank (n 11) 41-42.
} 
providing debtors with a fresh start, such debtors will have a better chance of becoming active in the economy and the formal sector - thereby encouraging and possibly stimulating economic growth. 